\title{
Use of platelet- and leukocyte-rich fibrin (L-PRF) as an alternative for tissue regeneration in sinus lift surgery
}

\author{
Uso de fibrina rica em plaquetas e leucócitos (L-PRF) como alternativa para a regeneração tecidual \\ em cirurgias de elevação do seio maxilar \\ Uso de fibrina rica en plaquetas y leucocitos (L-PRF) como alternativa para la regeneración tisular \\ en cirugías de elevación del seno maxilar
}

Received: 01/14/2022 | Reviewed: 01/21/2022 | Accept: 01/29/2022 | Published: 01/30/2022

Mauro Wilker Cruz de Azevedo

ORCID: https://orcid.org/0000-0002-6668-0665

Centro Universitário Fametro, Brazil

E-mail: maurowil.azevedo@gmail.com

Lucas Andeilson dos Santos Matos

ORCID: https://orcid.org/0000-0001-6258-7327

Centro Universitário Fametro, Brazil

E-mail: lucasmmatos@outlook.com

Tharlles Bruno Lima Silva

ORCID: https://orcid.org/0000-0002-8371-1697

Centro Universitário Fametro, Brazil

E-mail: tbrunolimas@gmail.com

Wállyson Alves e Silva

ORCID: https://orcid.org/0000-0003-2685-3282

Centro Universitário Maurício de Nassau, Brazil E-mail: wallysonalvees@gmail.com

Fabielly Camelo do Nascimento

ORCID: https://orcid.org/0000-0002-3089-2551

Centro Universitário Fametro, Brazil

E-mail: fabiellycamelo@hotmail.com

Thaís Monte Silva

ORCID: https://orcid.org/0000-0001-7255-6225

Centro Universitário das Faculdades Metropolitanas Unidas, Brazil

E-mail: montesilvathais@gmail.com

Laís Pereira Leal

ORCID: https://orcid.org/0000-0002-1870-2065

Centro Universitário Fametro, Brazil

E-mail: laispereiraleal@hotmail.com

Leyriane Mendes Paiva

ORCID: https://orcid.org/0000-0002-4691-4903

Centro Universitário Fametro, Brazil

E-mail: leyrianemp@gmail.com

Jandenilson Alves Brígido

ORCID: https://orcid.org/0000-0002-9590-0372

Centro Universitário Fametro, Brazil

E-mail: jandenilson@hotmail.com

\begin{abstract}
This study aimed to understand how fibrin rich in platelets and leukocytes acts as an alternative for tissue regeneration in surgeries for maxillary sinus elevation. This integrative review was developed in six steps, where the guiding question was formulated according to the PICo strategy. Thus, a total of 142 publications were searched and a total of 23 articles were selected for this review after applying the inclusion and exclusion criteria. Platelet- and leukocyterich fibrin (L-PRF) has been increasingly investigated as a potential bioactive substance for more effective bone regeneration, not only because it is considered an easily obtained autogenous material, but also due to its high concentration of fibrin, platelets and leukocytes, assisting in the process of angiogenesis, thanks to its growth factors, which contributes to bone formation when associated with grafts, as it multiplies fibroblasts and osteoblasts. Furthermore, for the surgical method, the use of L-PRF decreases the dispersion of the graft particles used, helping to condense more mineral and consequently resulting in a smaller volume introduced into the maxillary sinus, thus minimizing the time to obtain vertical bone height. However, since the preparation is properly autologous, the amount of L-PRF acquired is insufficient, causing a disadvantage in its use. In this sense, we realize the importance of L-PRF
\end{abstract}


in maxillary sinus elevation surgery, as it is a simple, cheap and the most accessible technique for the production of autologous fibrin membrane or platelet concentrate.

Keywords: Platelet-rich fibrin; Maxillary sinus; Bone regeneration.

\section{Resumo}

Este estudo teve como objetivo entender como a fibrina rica em plaquetas e leucócitos atua como alternativa para a regeneração tecidual em cirurgias de elevação do seio maxilar. Tal revisão integrativa foi desenvolvida em seis etapas, onde a questão norteadora foi formulada conforma a estratégia PICo, assim, foram realizadas buscas bibliográficas e entrados um total de 142 publicações, onde após a aplicação dos critérios de inclusão e exclusão, 23 artigos foram selecionados para esta revisão. A fibrina rica em plaquetas e leucócitos (L-PRF) tem sido cada vez mais investigada como uma potencial substância bioativa para uma regeneração óssea mais eficaz, não só por ser considerado um material autógeno de fácil obtenção, como também devido sua alta concentração de fibrina, plaquetas e leucócitos, auxiliando no processo de angiogênese, graças aos seus fatores de crescimento, o que contribui para a formação óssea quando associada a enxertos, pois multiplica fibroblastos e osteoblastos. Além disso, para o método cirúrgico, o uso da L-PRF diminui a dispersão das partículas de enxerto utilizadas, ajudando a condensar mais mineral e, consequentemente, resultando em um menor volume introduzido no seio maxilar, minimizando assim o tempo de obtenção da altura óssea vertical. Contudo, como a preparação é propriamente autóloga, a quantidade de L-PRF adquirida é insuficiente, causando uma desvantagem na sua utilização. Nesse sentido, percebe-se a importância do LPRF na cirurgia de elevação do seio maxilar, por ser uma técnica simples, barata e a mais acessível para a produção de membrana de fibrina autóloga ou concentrado de plaquetas.

Palavras-chave: Fibrina rica em plaquetas; Seio maxilar; Regeneração óssea.

\section{Resumen}

Este estudio tuvo como objetivo comprender cómo la fibrina rica en plaquetas y leucocitos actúa como alternativa para la regeneración tisular en las cirugías de elevación del seno maxilar. Esta revisión integradora se desarrolló en seis pasos, donde la pregunta guía se formuló según la estrategia PICo. Así, se buscaron un total de 142 publicaciones y se seleccionaron un total de 23 artículos para esta revisión tras aplicar los criterios de inclusión y exclusión. La fibrina rica en plaquetas y leucocitos (L-PRF) se ha investigado cada vez más como sustancia bioactiva potencial para una regeneración ósea más eficaz, no sólo porque se considera un material autógeno de fácil obtención, sino también por su alta concentración de fibrina, plaquetas y leucocitos, que ayuda en el proceso de angiogénesis, gracias a sus factores de crecimiento, lo que contribuye a la formación ósea cuando se asocia a los injertos, ya que multiplica los fibroblastos y los osteoblastos. Además, para el método quirúrgico, el uso de L-PRF disminuye la dispersión de las partículas de injerto utilizadas, ayudando a condensar más mineral y consecuentemente resultando en un menor volumen introducido en el seno maxilar, minimizando así el tiempo para obtener la altura ósea vertical. Sin embargo, al tratarse de una preparación propiamente autóloga, la cantidad de L-PRF adquirida es insuficiente, provocando una desventaja en su uso. En este sentido, nos damos cuenta de la importancia de la L-PRF en la cirugía de elevación del seno maxilar, ya que es una técnica sencilla, barata y la más accesible para la producción de membrana de fibrina autóloga o concentrado de plaquetas.

Palabras clave: Fibrina rica en plaquetas; Seno maxilar; Regeneración ósea.

\section{Introduction}

The paranasal sinuses can be defined as cavities inside the pneumatic bones of the face distributed in pairs, located in the frontal, sphenoid, ethmoid and maxillary bones. The latter is in the body of the maxillae and is the largest of the paranasal sinuses; however, its dimensions may change depending on the age, race and sex of the individual. In addition, another factor that can change the extent of the sinus is tooth loss or trauma to the upper molar region, which can lead to progressive bone resorption and decreased residual bone height in the posterior maxilla, thus causing intense pneumatization of the maxillary sinus (Nizam et al., 2018).

Thus, to make up for the deficiency of bone structure and allow oral rehabilitation of the edentulous area, sinus augmentation surgery has become an alternative with great predictability and good clinical results, in which a surgical procedure is performed to increase the amount of bone in the maxilla by elevating the sinus membrane, known as Schneider's membrane. The definition of the technique to be used for maxillary sinus elevation will depend on the thickness of the remaining local alveolar bone, since the success of the implant restoration depends to a large extent on sufficient bone volume and density. Among the techniques used are the atraumatic method with osteotomes, with immediate implant installation, as 
well as the lateral access or Caldwell-Luc technique (Liu et al., 2019).

In addition to the correct surgical execution, the selection of the biomaterial for grafting is of utmost importance for the success of the procedure, so autogenous bone, considered as one of the best materials, is well used for the filling of maxillary sinus insufficiency as this material has an osteogenic, osteoconductive and osteoinductive characteristic. Thus, in order to improve techniques and maximize the adhesion of bone grafting materials for maxillary sinus augmentation, more and more adjuvant strategies have been studied and proposed, including, platelet- and leukocyte-rich fibrin (L-PRF) has been widely used in dental implant surgeries due to its ability to reduce healing time and avoid perforation of the sinus membrane, in addition to being considered the cheapest and simplest technique to perform (Kim et al., 2017; Simonpieri et al., 2011).

The first report on the use of L-PRF was in 2001, in France, by the physician Joseph Choukroun, who classified it as a concentration of leukocyte and platelet fibrin, this technique belongs to the second generation of platelet aggregates, which was studied and developed to facilitate the obtaining and use of this biomaterial, its terminology, previously called PRF, was changed, with the inclusion of the "L", due to its higher content of leukocytes. L-PRF has been increasingly investigated as a potential bioactive substance for more effective bone regeneration, not only because it is considered an autogenous material that is readily available, but also due to its high concentration of fibrin, platelets, and leukocytes, aiding in the process of angiogenesis, as well as fibroblast and osteoblast multiplication (Choukroun et al., 2006; Zhang et al., 2012).

In view of this, the present study aims to understand the use of L-PRF as an alternative for tissue regeneration in sinus lift surgeries.

\section{Methodology}

The study is an integrative literature review, developed in six stages, namely: a) development of the research question; b) definition of the databases and inclusion criteria used; c) definition of the information to be extracted from the selected studies; d) evaluation of the included studies; e) interpretation of the results; f) presentation of the synthesis of knowledge (Whittemore \& Knafl, 2005).

The research question was posed according to the Population Context of Interest (PICo) strategy (Lockwood et al., 2017). Thus, the following structure was considered: P - platelet-rich fibrin (L-PRF), I - tissue regeneration from sinus lift surgery and Co - tissue regeneration. Thus, the following question was formulated: "Can the use of L-PRF be an alternative for tissue regeneration in sinus lift surgeries?".

The bibliographic searches were conducted in November 2021, using the Medical Literature Analysis and Retrival System Online (MEDLINE) databases through PubMed, EBSCOhost and Cochrane Library. To expand on the results found, handsearching was also employed by reading the references of the selected primary studies. Two groups of independent researchers, composed of three and four members, respectively, carried out the search and selection of studies, where they standardized the steps and performed them separately, to verify possible divergences in the findings.

For the search, English descriptors indexed in Medical Subject Headings (MeSH) were selected by crossing the controlled descriptors, combined with the Boolean operator AND and their synonyms (uncontrolled descriptors), associated with the Boolean operator OR (Figure 1), which were duly adapted according to the particularities of each database used in the study. 
Figure 1 - MeSH and uncontrolled descriptors used for the search strategy.

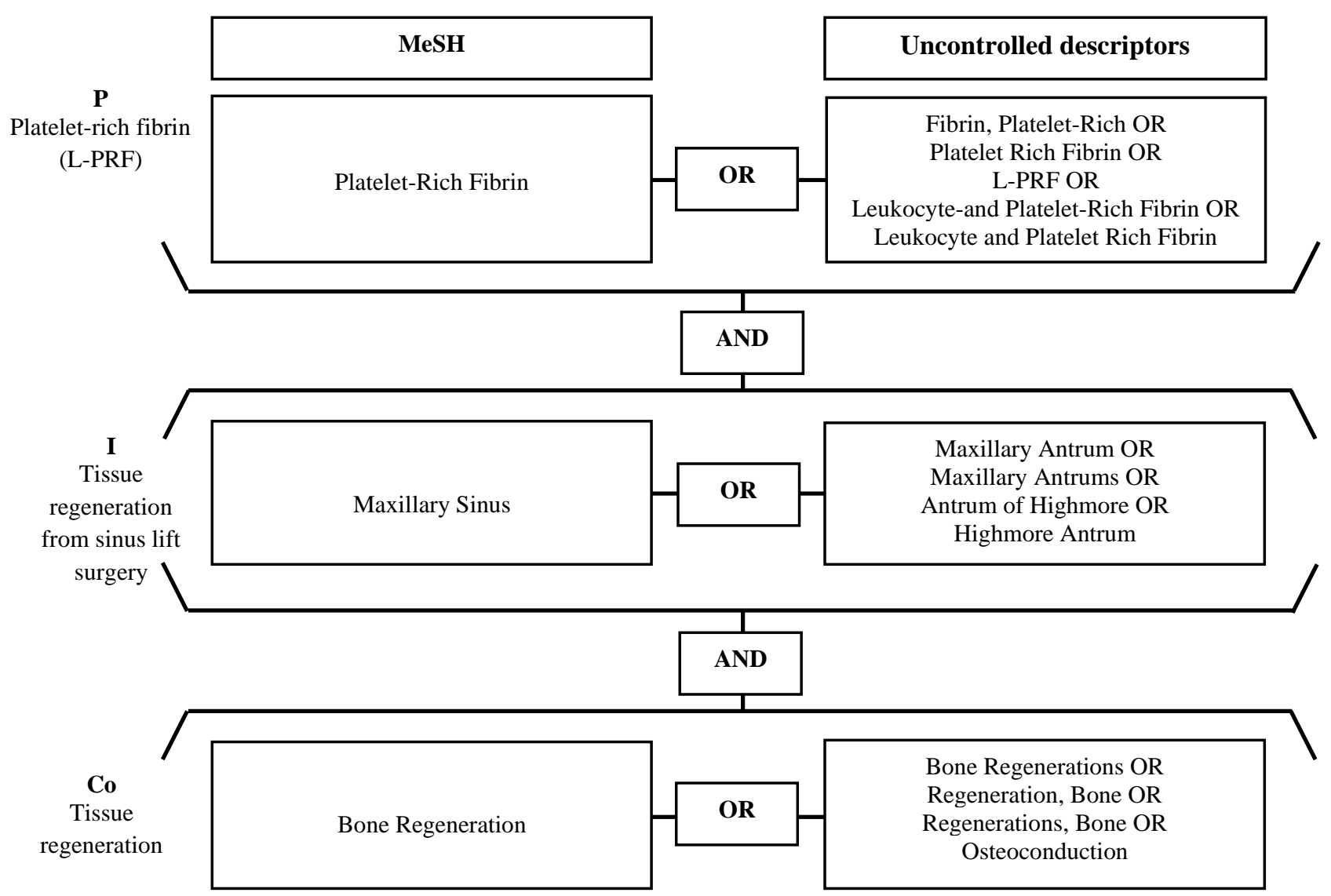

Source: Authors (2021).

The inclusion criteria adopted were: primary studies addressing the use of L-PRF as a tissue regeneration alternative in maxillary sinus lift surgeries, published between January 2011 and November 2021. The exclusion criteria were: editorials, theses, monographs, dissertations, gray literature, review articles, incomplete studies available electronically, duplicate articles and those that do not answer the research question.

As this was an integrative review, the research was not submitted to the Research Ethics Committee, but the authors' ideas about the publications used in the development of this study were maintained. The methodology for article selection and eligibility followed the Preferred Reporting Items for Systematic Reviews and Meta-Analyses (PRISMA) recommendations (Page et al., 2021), as shown in Figure 2. 
Figure 2 - Flowchart of primary study selection, based on the PRISMA recommendation.

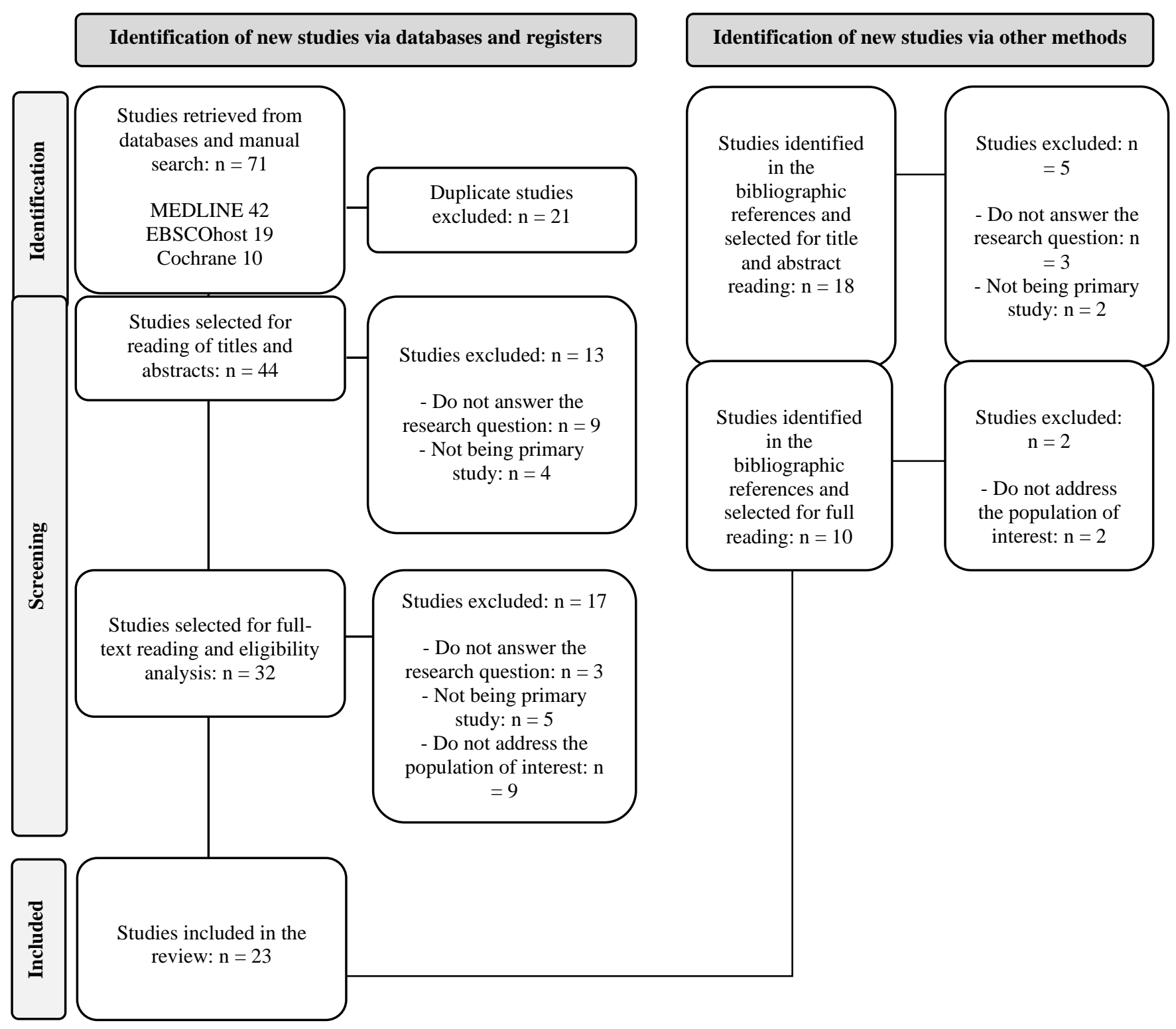

Source: Page et al. (2021).

\section{Results}

A total of 71 publications were retrieved from the search, of which, after applying the inclusion and exclusion criteria, 23 articles were selected to compose this review, distributed as follows: seven (30.43\%) in MEDLINE/PubMed, five (21.74\%) in EBSCOHost, three (13.04\%) in the Cochrane Library and eight (34.78\%) by manual search.

In terms of study design, 4 (17.39\%) were randomized clinical trials, 7 (30.43\%) in vivo studies, $5(21.74 \%)$ in vitro studies, $1(4.35 \%)$ clinical trial, $2(8.70 \%)$ prospective study, $2(8.70 \%)$ case series, and $2(8.70 \%)$ clinical case reports, published between 2011 and 2021, with a higher occurrence of publications in 2014 and 2015.

Table 1 shows the 23 publications selected according to the main author, year of publication, methodology, objective, and main results of the studies. 
Table 1 - Summary of selected primary studies.

\begin{tabular}{|c|c|c|c|}
\hline $\begin{array}{l}\text { AUTHOR/ } \\
\text { YEAR }\end{array}$ & METHODOLOGY & OBJECTIVE & MAIN FINDINGS \\
\hline CHOI, 2021 & In vivo study & $\begin{array}{l}\text { To evaluate the efficacy of fibrin sealant } \\
\text { (Tisseel®) on bone regeneration performance } \\
\text { in a rabbit maxillary sinus model. }\end{array}$ & $\begin{array}{l}\text { The results of this study suggest that, although the difference in } \\
\text { bone formation between group } 1 \text { and group } 2 \text { appears to be } \\
\text { insignificant, group } 2 \text { had an advantage in using fewer bone } \\
\text { substances to achieve reliable bone formation. }\end{array}$ \\
\hline $\begin{array}{l}\text { NIZAM, } \\
2018\end{array}$ & $\begin{array}{l}\text { Randomized clinical } \\
\text { trial }\end{array}$ & $\begin{array}{l}\text { To evaluate the effect of leukocyte- and } \\
\text { platelet-rich fibrin (L-PRF) in combination } \\
\text { with deproteinized bovine bone mineral } \\
\text { (DBBM) on bone regeneration in maxillary } \\
\text { sinus augmentation. }\end{array}$ & $\begin{array}{l}\text { Both techniques were effective for maxillary sinus augmentation } \\
\text { and, after } 6 \text { months of healing, the addition of L-PRF to DBBM did } \\
\text { not improve the amount of regenerated bone or the amount of graft } \\
\text { integrated with the neoformed bone on histologic and } \\
\text { histomorphometric evaluation. }\end{array}$ \\
\hline $\begin{array}{l}\text { PICHOTAN } \\
\text { O, } 2018\end{array}$ & Clinical case report & $\begin{array}{l}\text { To describe the effects of leukocyte- and } \\
\text { platelet-rich fibrin (L-PRF) associated with } \\
\text { demineralized bovine bone mineral (DBBM) } \\
\text { and absorbable collagen membrane (CM) on } \\
\text { bone regeneration in maxillary sinus } \\
\text { augmentation. }\end{array}$ & $\begin{array}{l}\text { Together, the two techniques were effective for maxillary sinus } \\
\text { augmentation, but the addition of L-PRF to the graft allowed early } \\
\text { implant placement and accelerated bone healing under the } \\
\text { conditions studied. }\end{array}$ \\
\hline KILIÇ, 2017 & $\begin{array}{l}\text { Randomized clinical } \\
\text { trial }\end{array}$ & $\begin{array}{l}\text { To compare histologic and histomorphometric } \\
\text { results of maxillary sinus floor augmentation } \\
\text { between b-TCP alone, b-TCP mixed with P- } \\
\text { PRP and b-TCP mixed with PRF. }\end{array}$ & $\begin{array}{l}\text { These results suggest that the addition of P-PRP or PRF to b-TCP } \\
\text { graft substitute was not beneficial for new bone formation and } \\
\text { regeneration, and that P-PRP plus b-TCP or PRF plus b-TCP is not } \\
\text { superior to b-TCP alone. }\end{array}$ \\
\hline $\begin{array}{l}\text { FUJIOKA-K } \\
\text { OBAYASHI, } \\
2017\end{array}$ & In vitro study & $\begin{array}{l}\text { To characterize how centrifugation speed (G- } \\
\text { force) along with centrifugation time influence } \\
\text { the release of growth factor from fibrin clots as } \\
\text { well as the cellular activity of gingival } \\
\text { fibroblasts exposed to each PRF matrix. }\end{array}$ & $\begin{array}{l}\text { Modifications in centrifugation speed and time with the low-speed } \\
\text { concept favor an increased release of the clot growth factor PRF. } \\
\text { This, in turn, can directly influence tissue regeneration by } \\
\text { increasing fibroblast migration, proliferation and collagen mRNA } \\
\text { levels. }\end{array}$ \\
\hline KIM, 2017 & In vivo study & $\begin{array}{l}\text { To compare the potentials of type I absorbable } \\
\text { collagen sponge (ACS) impregnated with } \\
\text { recombinant human bone morphogenetic } \\
\text { protein (rhBMP)-2, tricalcium phosphate } \\
\text { (TCP) coated with rhBMP-2, and TCP mixed } \\
\text { with platelet-rich fibrin to enhance bone } \\
\text { regeneration. }\end{array}$ & $\begin{array}{l}\text { There were no significant differences in inflammatory } \\
\text { characteristics between the groups at } 1 \text { week postoperatively. In a } \\
\text { histomorphometric analysis, the rate of new bone formation showed } \\
\text { significant differences between the groups at } 2 \text { weeks. }\end{array}$ \\
\hline AOKI, 2016 & Clinical case report & $\begin{array}{l}\text { Report two clinical cases with histologic } \\
\text { evaluation of PRF after surgery. }\end{array}$ & $\begin{array}{l}\text { The use of PRF as grafting material during sinus floor augmentation } \\
\text { induces natural bone regeneration. }\end{array}$ \\
\hline $\begin{array}{l}\text { KANAYAM } \\
\text { A, } 2016\end{array}$ & Prospective study & $\begin{array}{l}\text { To measure bone gain around the dental } \\
\text { implant after using the crestal approach for } \\
\text { sinus floor elevation using platelet-rich fibrin } \\
\text { as the sole grafting material in atrophic } \\
\text { posterior maxillae with a residual bone height } \\
\text { of } 5 \mathrm{~mm} \text {. }\end{array}$ & $\begin{array}{l}\text { Platelet-rich fibrin promoted endosseous bone gain when used as } \\
\text { graft material in the crestal approach for sinus floor elevation. }\end{array}$ \\
\hline $\begin{array}{l}\text { ANGELO, } \\
2015 \text {. }\end{array}$ & $\begin{array}{l}\text { Randomized clinical } \\
\text { trial }\end{array}$ & $\begin{array}{l}\text { To investigate at the clinical level the } \\
\text { biomechanical stability of augmented regions } \\
\text { in the maxillary bone when using a new class } \\
\text { of calcium phosphate biomaterials with and } \\
\text { without the addition of platelet-rich fibrin in } \\
\text { the enhanced subperiosteal tunneling } \\
\text { piezotome technique. }\end{array}$ & $\begin{array}{l}\text { The use of calcium phosphate biomaterials alone or combined with } \\
\text { platelet-rich fibrin appears to be favorable for achieving restored } \\
\text { alveolar bone with superior mechanical stability. }\end{array}$ \\
\hline $\begin{array}{l}\text { KOHAL } \\
2015\end{array}$ & $\begin{array}{l}\text { Randomized clinical } \\
\text { trial }\end{array}$ & $\begin{array}{l}\text { To investigate the amount of mineralization of } \\
\text { a bovine bone substitute in sinus floor } \\
\text { augmentation after healing times of } 3 \text { and } 6 \\
\text { months. }\end{array}$ & $\begin{array}{l}\text { Bone maturation in the sinus augmented with the bovine bone } \\
\text { material is similar after } 3 \text { and } 6 \text { months. Therefore, implant } \\
\text { installation at } 3 \text { months after a lateral window sinus floor } \\
\text { augmentation approach using a bovine bone material appears to be } \\
\text { clinically acceptable. }\end{array}$ \\
\hline $\begin{array}{l}\text { OLIVEIRA, } \\
2015\end{array}$ & In vivo study & $\begin{array}{l}\text { To investigate the effects of platelet-rich fibrin } \\
\text { (PRF) associated or not with Bio-Oss on bone } \\
\text { defects in the rat calvaria. }\end{array}$ & $\begin{array}{l}\text { At } 60 \text { days, the Bio-Oss associated groups had similar results, and } \\
\text { both showed statistical differences in relation to the other groups. }\end{array}$ \\
\hline $\begin{array}{l}\text { TANAKA, } \\
2015\end{array}$ & In vitro study & $\begin{array}{l}\text { To evaluate the additional effects of PRF on } \\
\text { bone regeneration in deproteinized bovine bone }\end{array}$ & $\begin{array}{l}\text { Additional effects of PRF may be found due to higher percentages } \\
\text { of new bone formation by the DBBM / PRF mixture than by }\end{array}$ \\
\hline
\end{tabular}




\begin{tabular}{|c|c|c|c|}
\hline & & mineral (DBBM) sinus augmentation. & subjects using DBBM alone, in previous reports. \\
\hline $\begin{array}{l}\text { GHANAATI, } \\
2014\end{array}$ & In vitro study & $\begin{array}{l}\text { Compare protocols for standard platelet-rich } \\
\text { fibrin (S-PRF) ( } 2700 \text { rpm, } 12 \text { minutes) and } \\
\text { advanced platelet-rich fibrin (A-PRF) (1500 } \\
\text { rpm, } 14 \text { minutes) to establish histological cell } \\
\text { detection and histomorphometric measurement } \\
\text { of cell distribution. }\end{array}$ & $\begin{array}{l}\text { Specific cell types are differentially distributed as a function of } \\
\text { (cumulative) centrifugal force. This concept allows tailoring the } \\
\text { optimal framework or composites for specific clinical applications. }\end{array}$ \\
\hline $\begin{array}{l}\text { JEONG, } \\
2014\end{array}$ & In vivo study & $\begin{array}{l}\text { To examine the effect of simultaneous sinus } \\
\text { elevation and implantation using platelet-rich } \\
\text { fibrin as the sole graft material on bone } \\
\text { formation in a canine sinus model. }\end{array}$ & $\begin{array}{l}\text { Simultaneous sinus lift and implantation using platelet-rich fibrin as } \\
\text { the sole grafting material is not a predictable and reproducible } \\
\text { procedure, especially with regard to bone formation around the } \\
\text { implants in the sinus cavity. }\end{array}$ \\
\hline XUAN, 2014 & In vivo study & $\begin{array}{l}\text { To compare the potentials of Bio-Oss mixed } \\
\text { with PRF and Bio-Oss mixed with Tisseel to } \\
\text { enhance bone regeneration in a canine sinus } \\
\text { model. }\end{array}$ & $\begin{array}{l}\text { The results of this study suggest that when platelet-rich fibrin is } \\
\text { used as an adjunct to Bio-Oss particles for bone augmentation in the } \\
\text { maxillary sinus, bone formation at the graft sites is significantly } \\
\text { greater than when Tisseel is used. }\end{array}$ \\
\hline YOON, 2014 & In vivo study & $\begin{array}{l}\text { To investigate the influence of platelet-rich } \\
\text { fibrin (PRF) on angiogenesis and osteogenesis } \\
\text { in guided bone regeneration (GBR) using } \\
\text { xenogeneic bone in rabbit cranial defects. }\end{array}$ & $\begin{array}{l}\text { The results of this study suggest that PRF can increase the number } \\
\text { of marrow cells. However, PRF together with xenogeneic bone } \\
\text { substitutes do not show a significant effect on bone regeneration. }\end{array}$ \\
\hline $\begin{array}{l}\text { GASSLING, } \\
2013\end{array}$ & Case series & $\begin{array}{l}\text { To evaluate the effect of PRF on bone } \\
\text { regeneration when used as a barrier membrane } \\
\text { at the site of lateral osteotomy in sinus } \\
\text { augmentation. }\end{array}$ & $\begin{array}{l}\text { Coverage of the lateral sinus window with two different absorbable } \\
\text { membranes has been shown to result in a similar amount of vital } \\
\text { bone formation and residual bone substitute. }\end{array}$ \\
\hline $\begin{array}{l}\text { TAJIMA, } \\
2013\end{array}$ & Prospective study & $\begin{array}{l}\text { To evaluate sinus floor augmentation with } \\
\text { simultaneous implant placement using platelet- } \\
\text { rich fibrin (PRF) as the sole graft material. }\end{array}$ & $\begin{array}{l}\text { Sinus lift with simultaneous implant placement using PRF as the } \\
\text { sole filler material can promote natural bone regeneration. }\end{array}$ \\
\hline KIM, 2012 & In vivo study & $\begin{array}{l}\text { To evaluate platelet-rich fibrin (PRF), mixed } \\
\text { tricalcium phosphate (TCP) and recombinant } \\
\text { human bone morphogenic protein-2 (rhBMP- } \\
\text { 2)-coated TCP for their potential to enhance } \\
\text { bone regeneration in sinus lift in rabbits, as } \\
\text { well as their inflammatory characteristics. }\end{array}$ & $\begin{array}{l}\text { In the results of histological evaluation (hematoxylin-eosin staining, } \\
\text { Masson's trichrome), experimental groups A and B showed rapid } \\
\text { bone formation, remodeling and calcification in the second week. In } \\
\text { addition, there was a significant difference between these } \\
\text { experimental groups and the control group in the area of bone } \\
\text { neoformation at the fourth, sixth and eighth weeks. }\end{array}$ \\
\hline $\begin{array}{l}\text { TATULLO, } \\
\quad 2012\end{array}$ & In vitro study & $\begin{array}{l}\text { To investigate, clinically and histologically, the } \\
\text { potential use of PRF associated with } \\
\text { deproteinized bovine bone (Bio-Oss) as } \\
\text { grafting material in severe maxillary atrophy } \\
\text { preimplant sinus grafts, compared to a control } \\
\text { group in which only deproteinized bovine bone } \\
\text { (Bio-Oss) was used as reconstruction material. }\end{array}$ & $\begin{array}{l}\text { The use of PRF and piezosurgery reduced the healing time } \\
\text { compared to the } 150 \text { days described in the literature, favoring } \\
\text { optimal bone regeneration. At } 106 \text { days, it is already possible to } \\
\text { achieve good primary stability of the endosseous implants, although } \\
\text { without functional loading. }\end{array}$ \\
\hline $\begin{array}{l}\text { ZHANG, } \\
2012\end{array}$ & In vitro study & $\begin{array}{l}\text { To evaluate the influence of PRF on bone } \\
\text { regeneration in sinus augmentation in } \\
\text { combination with a deproteinized bovine bone } \\
\text { xenograft. }\end{array}$ & $\begin{array}{l}\text { Our preliminary result showed neither advantages nor disadvantages } \\
\text { of the application of PRF in combination with deproteinized bovine } \\
\text { bone mineral in breast augmentation after a healing period of } 6 \\
\text { months. }\end{array}$ \\
\hline $\begin{array}{l}\text { SIMONPIER } \\
\quad \text { I, } 2011\end{array}$ & Case series & $\begin{array}{l}\text { To evaluate the relevance of sinus elevation } \\
\text { and simultaneous implantation with leukocyte- } \\
\text { and platelet-rich fibrin (L-PRF, Choukroun } \\
\text { technique) as the sole sinus filler material. }\end{array}$ & $\begin{array}{l}\text { The use of L-PRF as a single filler material during sinus lift and } \\
\text { simultaneous implantation appears to be a reliable surgical option, } \\
\text { which promotes natural bone regeneration. }\end{array}$ \\
\hline $\begin{array}{l}\text { THORAT, } \\
2011\end{array}$ & $\begin{array}{l}\text { Controlled clinical } \\
\text { trial }\end{array}$ & $\begin{array}{l}\text { To investigate the clinical and radiological } \\
\text { efficacy of autologous PRF in the treatment of } \\
\text { intraosseous defects in patients with chronic } \\
\text { periodontitis. }\end{array}$ & $\begin{array}{l}\text { Within the confines of the present study, there was a greater } \\
\text { reduction in probing depth, a greater gain in clinical attachment } \\
\text { level, and greater intraosseous defect fill in areas treated with PRF } \\
\text { than with open flap debridement alone. }\end{array}$ \\
\hline
\end{tabular}

Source: Authors (2021).

\section{Discussion}

In recent years, many studies have been carried out to investigate the efficacy of using L-PRF as an auxiliary material for bone grafting in sinus augmentation surgeries. This biomaterial is able to stimulate angiogenesis thanks to its growth 
factors platelet-derived growth factor (PDGF), insulin-like growth factor (IGF), vascular endothelial growth factor (VEGF), transforming growth factor beta (TGF- $\beta$ ) and angiogenic factor, and contributes to bone formation when associated with grafts, because it multiplies fibroblasts and osteoblasts, as well as, it has important effects of regularization of the inflammation process and stimulation of the immune process of chemotaxis, this is because plasma is an autologous graft material, able to eliminate any risk of disease proliferation Moreover, its consistent and gelatinous form favors the stability of the graft material and the clot (Tatullo et al., 2012 ; Nizam et al., 2018).

The time required for new bone formation is strictly related to the volume of graft used. Therefore, a large volume of grafted material in the maxillary sinus requires more time before any procedure is performed. In the in vivo study by Xuan et al. (2014), platelet-rich fibrin was found to decrease the dispersion of the graft particles used, helping to condense more mineral and consequently resulting in a smaller volume introduced into the maxillary sinus, thus minimizing the time to obtain vertical bone height.

L-PRF can be obtained by manual or automated methods, however, the most used technique is the one described by Choukroun, in which, prior to surgery, a $10 \mathrm{~mL}$ sample of peripheral blood is collected from the patient and $5 \mathrm{~mL}$ is distributed in two sterile tubes without anticoagulants, where it is centrifuged at $3000 \mathrm{rpm}$ for 10 minutes at room temperature. Upon centrifugation of the sample, the coagulation cascade is activated by the contact of the blood platelets and the tube, triggering the circulation of blood thrombin, and transforming fibrinogen into fibrin. After centrifugation, three distinct layers are formed in the tube, the first consisting of platelet-poor plasma, the second of a natural fibrin clot, and the third of red blood cells (Kiliç et al., 2017; Gassling et al., 2013).

In addition, the surgical approach will be established by a thorough preoperative evaluation, conduit, the lateral access technique is considered the safest when combined with the use of autologous grafts and is considered the gold standard in sinus lift surgeries. The procedure is performed starting with an ostectomy on the buccal side of the maxilla, forming a bony window that allows visualization of Schneider's membrane, which will be carefully detached and repositioned more posteriorly. From there, a mixture of L-PRF and the graft material chosen for the case is introduced into the sinus cavity, and finally an absorbable collagen membrane is applied to cover the entire obturated lateral window (Pichotano et al., 2018;).

Because the preparation is properly autologous, the amount of L-PRF acquired is insufficient, causing a disadvantage in its use since the amount produced is poor and only a restricted volume can be used. Thus, the use of L-PRF is limited in general surgery, for example, although its potential applications are wide, requiring a practical and precise knowledge of the biomaterial used, its biology, its limits and efficiencies to improve its use in daily practice. In addition, the surgery itself may also offer complications, as a perfect elevation of the membrane, without tears or injuries, is necessary to obtain a better result (Kohal et al., 2015).

In a study by Simonpieri et al. (2011) in 20 patients requiring implants, lateral window surgeries with simultaneous implant installation were performed. L-PRF clots were used to cover the osteotomy window and protect the Schneider membrane prior to implant drilling. The maximum follow-up of the study was six years, and all patients were followed for a minimum period of two years. As a result, no implants were lost during the entire study period and vertical bone gain could be observed in all patients, demonstrating how the use of platelet-rich fibrin can promote graft site protection and aid natural bone repair.

The findings of this integrative review point to scientific evidence on the use of L-PRF as an alternative for tissue regeneration in maxillary sinus elevation surgeries, contributing directly to dentistry, especially in dental surgery. The main limitations of this study are the large number of in vitro and animal studies, which makes it difficult to sample the results in clinical routine, requiring more randomized and controlled clinical trials, as well as long-term prospective studies. 


\section{Conclusion}

Based on the above, the importance of L-PRF in maxillary sinus elevation surgery can be perceived, since it is a simple, cheap and the most accessible technique to produce an autologous fibrin membrane or platelet concentrate. L-PRF when used as a surgical adjuvant, associated with a bone graft material in sinus lift procedures, successfully promotes vertical bone gain, accelerating bone neoformation and is also commonly used to protect Schneider's membrane during surgery, as well as accelerating local healing due to the release of growth factors. However, although there are studies exploring the efficacy of using L-PRF in sinus lift surgeries, the current evidence is limited, and many investigators still do not fully understand the effects of this biomaterial. In addition, different L-PRF preparation techniques are observed in the included studies, which may contribute to a wide range of possibilities. Therefore, based on the inconclusive results of the current literature, further studies, with larger sample size and long-term follow-up as parameters, are needed to confirm the predictability of this procedure and the standardization of the way of preparation, as well as to understand which types of grafts provide better clinical outcomes when combined with L-PRF.

\section{References}

Angelo, T., Marcel, W., Andreas, K., \& Izabela, S. (2015). Biomechanical stability of dental implants in augmented maxillary sites: results of a randomized clinical study with four different biomaterials and PRF and a biological view on guided bone regeneration. BioMed Research International, 2015.

Aoki, N., Kanayama, T., Maeda, M., Horii, K., Miyamoto, H., Wada, K., \& Shibuya, Y. (2016). Sinus augmentation by platelet-rich fibrin alone: A report of two cases with histological examinations. Case reports in dentistry, 2016.

Choi, W. H., Kim, Y. D., Song, J. M., \& Shin, S. H. (2021). Comparative study of bone regeneration using fibrin sealant with xenograft in rabbit sinus: pilot study. Maxillofacial Plastic and Reconstructive Surgery, 43(1), 1-6.

Choukroun, J., Diss, A., Simonpieri, A., Girard, M. O., Schoeffler, C., Dohan, S. L., \& Dohan, D. M. (2006). Platelet-rich fibrin (PRF): a second-generation platelet concentrate. Part IV: clinical effects on tissue healing. Oral Surgery, Oral Medicine, Oral Pathology, Oral Radiology, and Endodontology, 101(3), e56-e60.

Fujioka-Kobayashi, M., Miron, R. J., Hernandez, M., Kandalam, U., Zhang, Y., \& Choukroun, J. (2017). Optimized platelet-rich fibrin with the low-speed concept: growth factor release, biocompatibility, and cellular response. Journal of periodontology, 88(1), 112-121.

Galvão, C. M. (2006). Editorial. Níveis de evidência. Acta Paul Enferm, 19(2), 5.

Gassling, V., Purcz, N., Braesen, J. H., Will, M., Gierloff, M., Behrens, E., \& Wiltfang, J. (2013). Comparison of two different absorbable membranes for the coverage of lateral osteotomy sites in maxillary sinus augmentation: a preliminary study. Journal of Cranio-Maxillofacial Surgery, 41 (1), 76-82.

Ghanaati, S., Booms, P., Orlowska, A., Kubesch, A., Lorenz, J., Rutkowski, J., \& Choukroun, J. (2014). Advanced platelet-rich fibrin: a new concept for cellbased tissue engineering by means of inflammatory cells. Journal of Oral Implantology, 40(6), 679-689.

Jeong, S. M., Lee, C. U., Son, J. S., Oh, J. H., Fang, Y., \& Choi, B. H. (2014). Simultaneous sinus lift and implantation using platelet-rich fibrin as sole grafting material. Journal of Cranio-Maxillofacial Surgery, 42(6), 990-994.

Kanayama, T., Horii, K., Senga, Y., \& Shibuya, Y. (2016). Crestal approach to sinus floor elevation for atrophic maxilla using platelet-rich fibrin as the only grafting material: a 1-year prospective study. Implant dentistry, 25(1), 32-38.

Kılıç, S. C., Güngörmüş, M., \& Parlak, S. N. (2017). Histologic and histomorphometric assessment of sinus-floor augmentation with beta-tricalcium phosphate alone or in combination with pure-platelet-rich plasma or platelet-rich fibrin: A randomized clinical trial. Clinical implant dentistry and related research, 19(5), 959-967.

Kim, B. J., Kwon, T. K., Baek, H. S., Hwang, D. S., Kim, C. H., Chung, I. K., \& Shin, S. H. (2012). A comparative study of the effectiveness of sinus bone grafting with recombinant human bone morphogenetic protein 2-coated tricalcium phosphate and platelet-rich fibrin-mixed tricalcium phosphate in rabbits. Oral surgery, oral medicine, oral pathology and oral radiology, 113(5), 583-592.

Kim, C. H., Ju, M. H., \& Kim, B. J. (2017). Comparison of recombinant human bone morphogenetic protein-2-infused absorbable collagen sponge, recombinant human bone morphogenetic protein-2-coated tricalcium phosphate, and platelet-rich fibrin-mixed tricalcium phosphate for sinus augmentation in rabbits. Journal of dental sciences, 12(3), 205-212.

Kohal, R. J., Gubik, S., Strohl, C., Stampf, S., Bächle, M., Hurrle, A. A., \& Patzelt, S. B. M. (2015). Effect of two different healing times on the mineralization of newly formed bone using a bovine bone substitute in sinus floor augmentation: A randomized, controlled, clinical and histological investigation. Journal of clinical periodontology, 42(11), 1052-1059.

Liu, R., Yan, M., Chen, S., Huang, W., Wu, D., \& Chen, J. (2019). Effectiveness of platelet-rich fibrin as an adjunctive material to bone graft in maxillary sinus augmentation: a meta-analysis of randomized controlled trails. BioMed research international, 2019. 
Lockwood, C., Porrit, K., Munn, Z., Rittenmeyer, L., Salmond, S., Bjerrum, M., \& Stannard, D. (2017). Systematic reviews of qualitative evidence. JBI Reviewer's Manual [internet], 23-71.

Nizam, N., Eren, G., Akcali, A., \& Donos, N. (2018). Maxillary sinus augmentation with leukocyte and platelet-rich fibrin and deproteinized bovine bone mineral: A split-mouth histological and histomorphometric study. Clinical oral implants research, 29(1), 67-75.

Oliveira, M. R., Silva, A. D., Ferreira, S., Avelino, C. C., Garcia Jr, I. R., \& Mariano, R. C. (2015). Influence of the association between platelet-rich fibrin and bovine bone on bone regeneration. A histomorphometric study in the calvaria of rats. International journal of oral and maxillofacial surgery, 44(5), 649-655.

Page, M. J., McKenzie, J. E., Bossuyt, P. M., Boutron, I., Hoffmann, T. C., Mulrow, C. D., \& Moher, D. (2021). The PRISMA 2020 statement: an updated guideline for reporting systematic reviews. Bmj, 372

Pichotano, E. C., de Molon, R. S., Freitas de Paula, L. G., de Souza, R. V., Marcantonio Jr, E., \& Zandim-Barcelos, D. L. (2018). Early placement of dental implants in maxillary sinus grafted with leukocyte and platelet-rich fibrin and deproteinized bovine bone mineral. Journal of Oral Implantology, 44(3), 199206.

Simonpieri, A., Choukroun, J., Del Corso, M., Sammartino, G., \& Ehrenfest, D. M. D. (2011). Simultaneous sinus-lift and implantation using microthreaded implants and leukocyte-and platelet-rich fibrin as sole grafting material: a six-year experience. Implant dentistry, 20(1), 2-12.

Tajima, N., Ohba, S., Sawase, T., \& Asahina, I. (2013). Evaluation of sinus floor augmentation with simultaneous implant placement using platelet-rich fibrin as sole grafting material. International Journal of Oral \& Maxillofacial Implants, 28(1).

Tanaka, H., Toyoshima, T., Atsuta, I., Ayukawa, Y., Sasaki, M., Matsushita, Y., \& Nakamura, S. (2015). Additional effects of platelet-rich fibrin on bone regeneration in sinus augmentation with deproteinized bovine bone mineral: preliminary results. Implant dentistry, 24(6), 669-674.

Tatullo, M., Marrelli, M., Cassetta, M., Pacifici, A., Stefanelli, L. V., Scacco, S., \& Inchingolo, F. (2012). Platelet Rich Fibrin (PRF) in reconstructive surgery of atrophied maxillary bones: clinical and histological evaluations. International journal of medical sciences, 9(10), 872.

Thorat, M., Pradeep, A. R., \& Pallavi, B. (2011). Clinical effect of autologous platelet-rich fibrin in the treatment of intra-bony defects: a controlled clinical trial. Journal of clinical periodontology, 38(10), 925-932.

Whittemore, R., \& Knafl, K. (2005). The integrative review: updated methodology. Journal of advanced nursing, 52(5), 546-553.

Xuan, F., Lee, C. U., Son, J. S., Jeong, S. M., \& Choi, B. H. (2014). A comparative study of the regenerative effect of sinus bone grafting with platelet-rich fibrin-mixed Bio-Oss ${ }^{\circledR}$ and commercial fibrin-mixed Bio-Oss®: an experimental study. Journal of Cranio-Maxillofacial Surgery, 42(4), e47-e50.

Yoon, J. S., Lee, S. H., \& Yoon, H. J. (2014). The influence of platelet-rich fibrin on angiogenesis in guided bone regeneration using xenogenic bone substitutes: A study of rabbit cranial defects. Journal of Cranio-Maxillofacial Surgery, 42(7), 1071-1077.

Zhang, Y., Tangl, S., Huber, C. D., Lin, Y., Qiu, L., \& Rausch-Fan, X. (2012). Effects of Choukroun's platelet-rich fibrin on bone regeneration in combination with deproteinized bovine bone mineral in maxillary sinus augmentation: a histological and histomorphometric study. Journal of Cranio-Maxillofacial Surgery, 40(4), 321-328. 